\title{
Cranioplasty Following Firearm Injury in Patients from War in Yemen: Retrospective Review of 23 Patients
}

\author{
MOHAMED E. ELHAWARY, M.D.* and MICHAEL Z. JOHNY, M.D.** \\ The Department of Neurosurgery, Faculty of Medicine, Benha University* and Nasser Institute Hospital**
}

\begin{abstract}
Background: Cranioplasty, the repair of a skull vault defect by insertion of an object (bone or nonbiological materials such as metal or plastic plates), is a well-known procedure in modern neurosurgery. Brain protection and cosmetic aspects are the major indications of cranioplasty.
\end{abstract}

Aim of Study: This study is to compare the cosmetic outcome and complications rate after cranioplasty in patients with firearm injuries, coming from war in Yemen to our neurosurgery center in Egypt, with cranial bony defects.

\section{Patients and Methods:}

Patients were selected with the following inclusion criteria:

1- Size of defect: Patients with bony defects more than $3 \mathrm{~cm}$.

2- Location of the defect: Frontal, parietal and occipital defects, (temporal defects are covered with muscle and usually doesn't need repair).

We reviewed 23 patients retrospectively, underwent cranioplasty between March 2017 and November 2018. Titanium mesh (TM; 17 patients) and poly methyl methylacrylate (bone cement) reconstructed grafts (BC; 6 patients) were used as implants.

Results: More than $95 \%$ of cases (22 patients) presented to us with history of primary wound debridement, bullet extraction (in some cases) and wound closure in Yemen before coming to our center in Egypt.

Before surgery, $18.8 \%$ (4 patients) presented with pseudomeningiocele formation, 2 patients presented with CSF leaking skin fistula.

Intra-operatively, $82.6 \%$ (19 patients) of them didn't undergo any kind of duroplasty.

Regardless of implanted materials, more than $82.6 \%$ (19 patients) of the CP patients were satisfied with the cosmetic outcome. No statistically significant difference was observed among the two groups.

The TM group showed lower complication rates compared with $\mathrm{BC}$ group, while the $\mathrm{BC}$ group demonstrated a higher post-CP subgaleal collection rate $(33.3 \%, 2$ patients) than the TM group (5.8\%, 1 patient). However, no significant difference

Correspondence to: Dr. Mohamed E. Elhawary, The Department of Neurosurgery, Faculty of Medicine, Benha University in the incidence of post-CP infection was observed among the two groups.

Conclusion: In comparison with $\mathrm{TM}$ and $\mathrm{BC}$, cranioplasty with TM shows benefits in terms of lower post-CP complication, less intraoperative bleeding loss, shorter operation time and in-hospital stay.

Key Words: Cranioplasty - Cranial bone defect-Firearm injury - War in Yemen.

\section{Introduction}

CRANIOPLASTY is a surgical repair of a defect or deformity of a skull. Cranioplasty is almost as ancient as trepanation, the first bone graft was recorded by Job Janszoon van Meekeren, who in 1668 noted that canine bone was used to repair a cranial defect in a Russian man.

The use of autografts for cranioplasty was used in the early 20 th century, but was largely abandoned due to high infection and absorption rates, polymethyl methacrylate (PMMA) was introduced in 1940 and is currently the most common material used, 3 -D techniques are often used to work out plate sizes.

Gunshot wounds to the head, the predominant cause of penetrating head injury, usually cause massive destruction of brain tissue, severe brain swelling, and if transcranial trajectory, death.

The wounding potential of a bullet depends primarily on its velocity at impact and its mass, although the shape of the bullet and its lateral movements also play a role. The impact velocity is by far the most important determinant of a bullet's wounding potential. Consequently, high-velocity rifle wounds to the head are invariably fatal, whereas low-velocity open-chambered handgun wounds often are not [1] 
When a bullet enters the skull, it creates a variety of pressure waves within the brain, some of which can cause tissue pressures of nearly 100 atmospheres, resulting in further tissue injury. Bullets often fragment after they strike the skull, fracturing a portion of the skull into multiple fragments. Both the bullet and the bone fragments then become numerous secondary missiles that cause additional tissue damage.

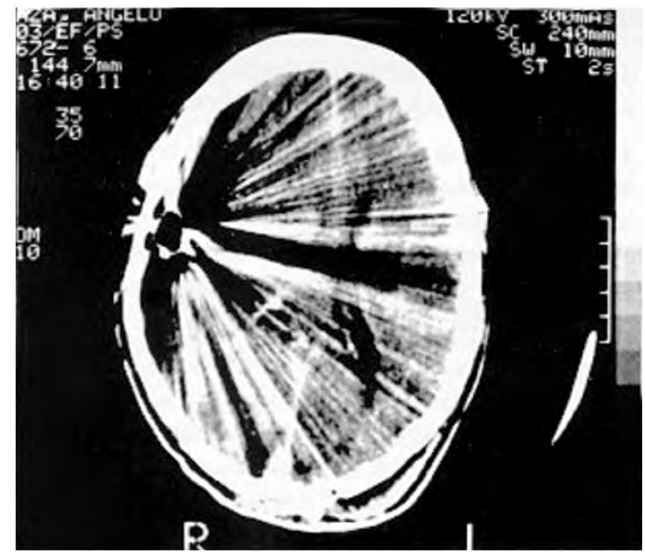

Fig. (1): Intracranial bullet injury.

Civilian Penetrating Brain Injuries (PBI) has high mortality rates that remain refractory to medical and neurosurgical advances based on the most recent case series [3], the reported civilian mortality rates from gunshot wounds to the head (GSWH) in the literature range from $23 \%$ to $92 \%$ [4], death from PBI occurs shortly after injury with $70 \%$ of patients succumbing after the first 24 hours [5].

\section{Pathophysiology:}

Two major mechanisms of tissue damage are recognized: Tissue crushing (or permanent cavitation) and temporary cavitation (or tissue stretching). The projectile itself crushes the brain in its path, creating a permanent track of injury. Projectiles traveling at higher velocities carry more kinetic energy and cause more damage [6]

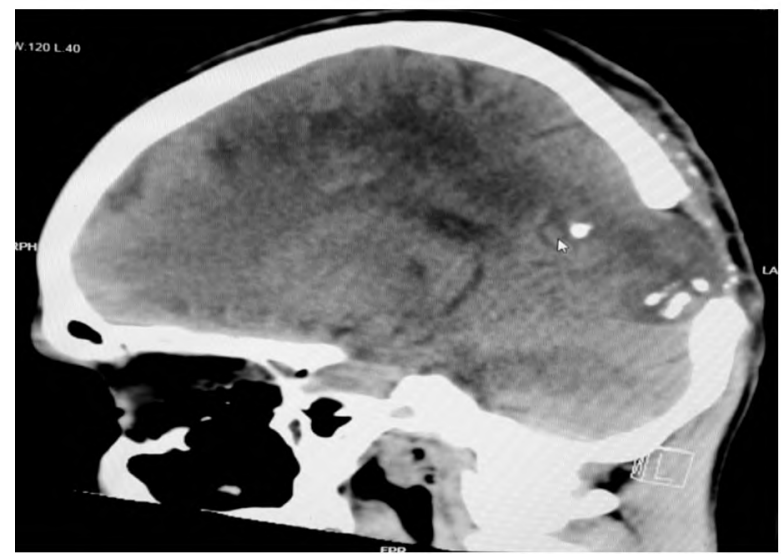

Fig. (2): Bullet track tissue damage.
Initial neurologic cell death occurs immediately in and around the trajectory of the penetrating object. Subsequent or secondary cell death can occur as a result of increased ICP, mass effect from space-occupying lesions, stroke from vessel injury or delayed ischemic neurologic deficits resulting from traumatic vasospasm, complications from infection, uncontrolled seizure activity, and delayed hydrocephalus [7]

\section{Material and Methods}

From March 2017 to November 2018, 23 CP procedures were performed in with two different materials, the mean age was 34.5 years, ranging from 18 to 51 years. Patients were classified into two groups: TM group Fig. (3) group, and BC Fig. (4) group.

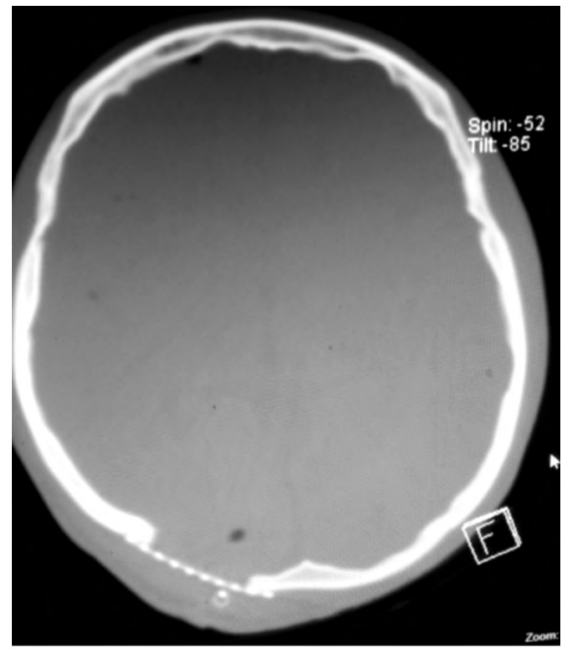

Fig. (3): Titanium Mesh.

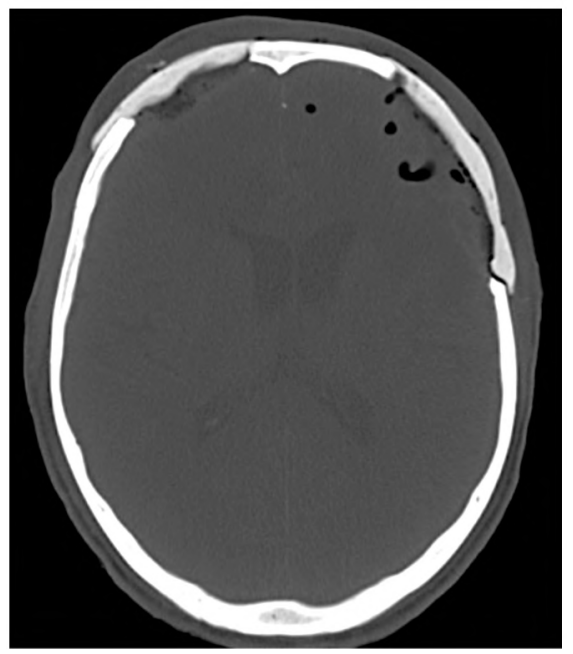

Fig. (4): Bone Cement.

We reviewed the parameters including age, sex, the presence of multiple fractures within the bone flap, implant material, intraoperative blood loss 
(mL), operative time and duration of hospital stay (days).

The clinical outcome was evaluated by assessing the cosmetic outcome after CP.

Cosmetic outcomes were obtained from patients or patient's relatives who visited the out-patient clinic during the follow-up periods.

Cosmetic outcome was categorized into three categories: (1) Complete satisfaction, satisfied with appearance; (2) Partial satisfaction, satisfied with appearance but not ideal (e.g., temporal dimple); and (3) Unsatisfactory, unsatisfied with appearance or requiring a revision surgery.

Complications were retrospectively reviewed according to the medical records of each patient. Complications included post-CP infection, wound dehiscence, post-operative hemorrhage and implant displacement. Post-CP infection was by confirmed by elevated C-reactive protein and abnormal increase in fluid collection revealed in post-operative enhanced computed tomography or magnetic resonance scan.

\section{Results}

Between March 2017 and November 2018, 23 patients underwent $\mathrm{CP}$ with two different materials at our institution. The $\mathrm{CP}$ with TM was conducted in 17 patients; $\mathrm{CP}$ with $\mathrm{BC}$ was performed in 6 patients.

The mean clinical and radiological follow-up was 6 months. The patients were all males. The mean age of patients at the time of CP was 34.5 years (range, 18-51). No statistically significant difference in demographics was observed among the groups.

Comparison of cosmetic outcomes, operation time, bleeding loss and hospital stay:

Titanium mesh has the advantage of lower infection and inflammatory reaction rates, while the main disadvantages are that it's expensive, has poor malleability and may cause artifacts in CT and MRI scans.

Poly methyl methylacrylate (bone cement) has excellent cosmosis, low cost, excellent malleability and durability, while main concerns are higher infection rates, exothermic and inflammatory reactions.

The cosmetic outcomes in the TM group including 15 patients were completely satisfactory; partially satisfactory in 2 patients and no unsatisfactory patients at all. The corresponding cosmetic outcomes in the BC group were 4, 2, and 0 respectively.

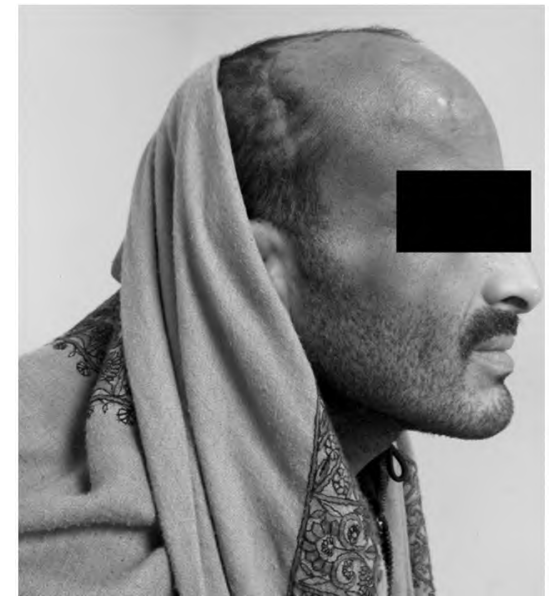

Fig. (5): Cosmetic outcome following cranioplasty.

Duration of hospitalization and intra-operative parameters were also evaluated. The TM group demonstrated the shortest in-hospital stay compared with the other BC group.

Regarding the intraoperative parameters, patients in the TM group experienced the shorter operation time and less blood loss, 19 patients required intra-operative duroplasty, 4 patients presented with pseudomeningiocele formation secondary to defective primary dural repair, while one patient presented with leaking CSF fistula with associated infection. Clinical outcomes are summarized in (Table 1).

\begin{tabular}{|c|c|c|}
\hline & $\begin{array}{c}\text { Titanum } \\
\text { Mesh group }\end{array}$ & $\begin{array}{c}\text { Bone } \\
\text { Cement group }\end{array}$ \\
\hline Number of patients & 17 & 6 \\
\hline Mean age (years) & $34.5(18-51)$ & $43(35-51)$ \\
\hline $\begin{array}{l}\text { Implant size }\left(\mathrm{cm}^{2}\right): \\
\quad<10 \mathrm{~cm} \\
\quad>10 \mathrm{~cm}^{2}\end{array}$ & $\begin{array}{l}14 \\
3\end{array}$ & $\begin{array}{l}6 \\
0\end{array}$ \\
\hline $\begin{array}{l}\text { Timing of surgery (days): } \\
\quad \text { Early }(<60) \\
\text { Late }(>60)\end{array}$ & $\begin{array}{l}12 \\
5\end{array}$ & $\begin{array}{l}1 \\
5\end{array}$ \\
\hline $\begin{array}{l}\text { Site of cranioplasty: } \\
\text { Frontal } \\
\text { Parietal } \\
\text { Occipital }\end{array}$ & $\begin{array}{l}7 \\
4 \\
6\end{array}$ & $\begin{array}{l}5 \\
1 \\
0\end{array}$ \\
\hline $\begin{array}{l}\text { Intraoperative findings: } \\
\text { Blood loss (mL) } \\
\text { Operation time (minutes) } \\
\text { Need for duroplasty }\end{array}$ & $\begin{array}{l}\text { Mean } \sim 200 \mathrm{ml} \\
\text { Mean } \sim 45 \text { minute } \\
16\end{array}$ & $\begin{array}{l}\text { Mean } \sim 350 \mathrm{ml} \\
\text { sMean } \sim 70 \text { minutes } \\
3\end{array}$ \\
\hline $\begin{array}{l}\text { Cosmetic outcome: } \\
\text { Complete satisfaction } \\
\text { Partial satisfaction } \\
\text { Unsatisfactory }\end{array}$ & ${ }_{0}^{15}$ (dimpled skin) & $\begin{array}{l}4 \\
2 \text { (subgaleeal } \\
\text { collection) } \\
0\end{array}$ \\
\hline Average hospital stay & Mean $\sim 5$ days & Mean $\sim 12$ days \\
\hline
\end{tabular}




\section{Discussion}

Case discussions:

1- 28 years old male patient, presented to ER in our center with DCL (E3, V2, M6) and right sided weakness (G. IV) following cranial firearm injury in Yemen 14 days ago.

Initial CT scans showed left frontal intracranial bullet, with subsequent right cranial bony defect.

Patient scheduled for operation the second day after stabilization of his general condition.

Intra-operatively, we did duroplasty using autologous facia lata graft, and cranial bony defect was closed using titanium mesh graft.

\section{Pre-operative images:}
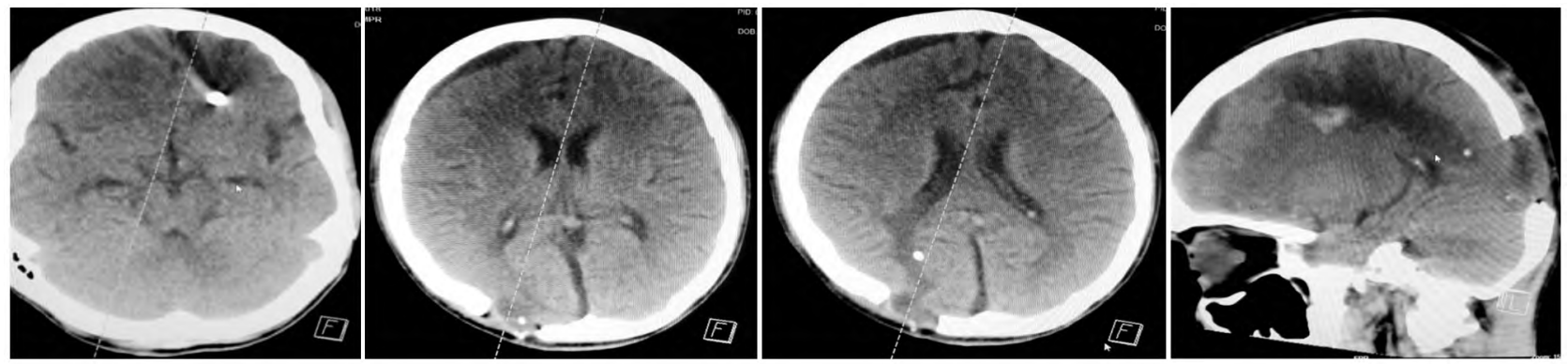

Intra-operative images:
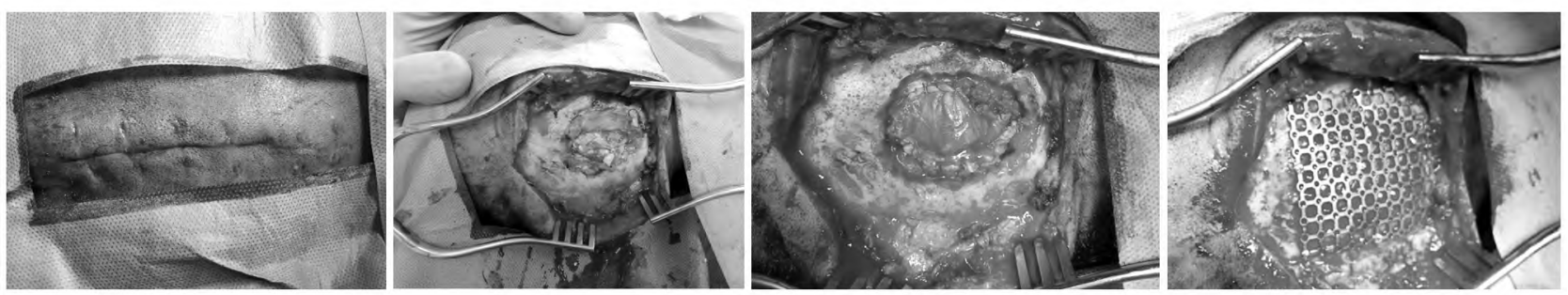

Post-operative images:
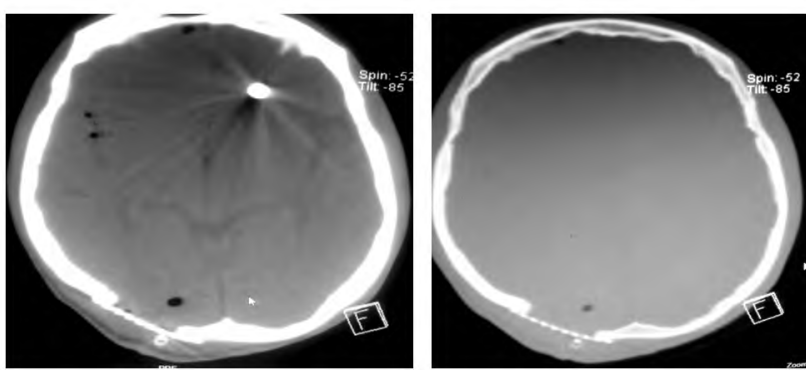

Patient stayed in ICU for 3 days, then in neurosurgical ward, on antibiotics and antiepileptics. Right sided weakness improved on dehydrating measures, he had smooth post-op. period without any complications and discharged after 10 days.

2- 40 years old male patient, presented to ER in our center with CSF leak from cranial wound

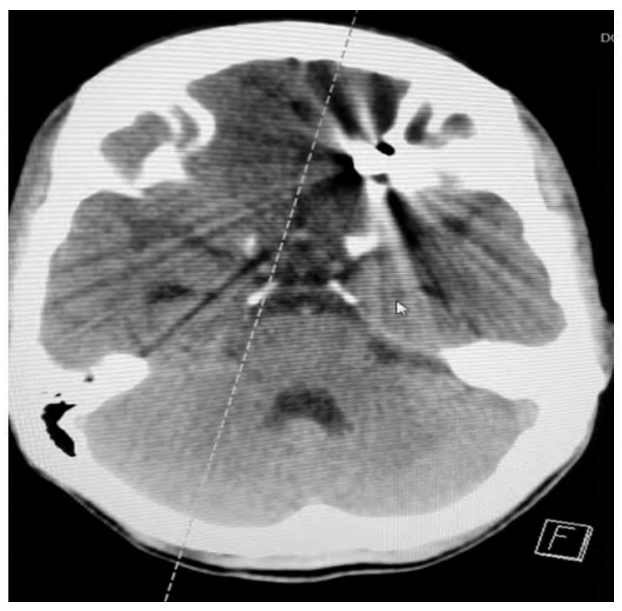

Fig. (6): Intracranial bullet. 
Pre-operative images:
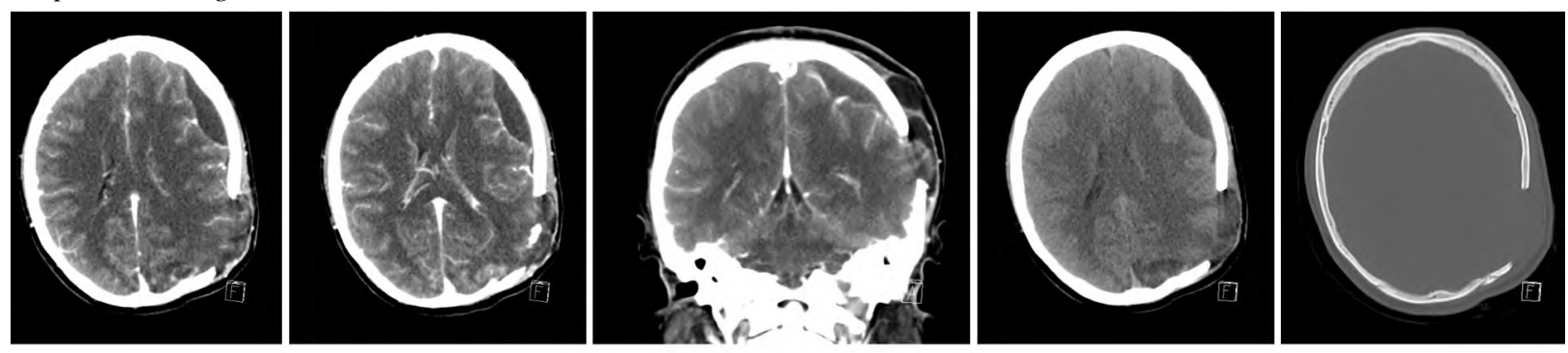

Post-operative images:
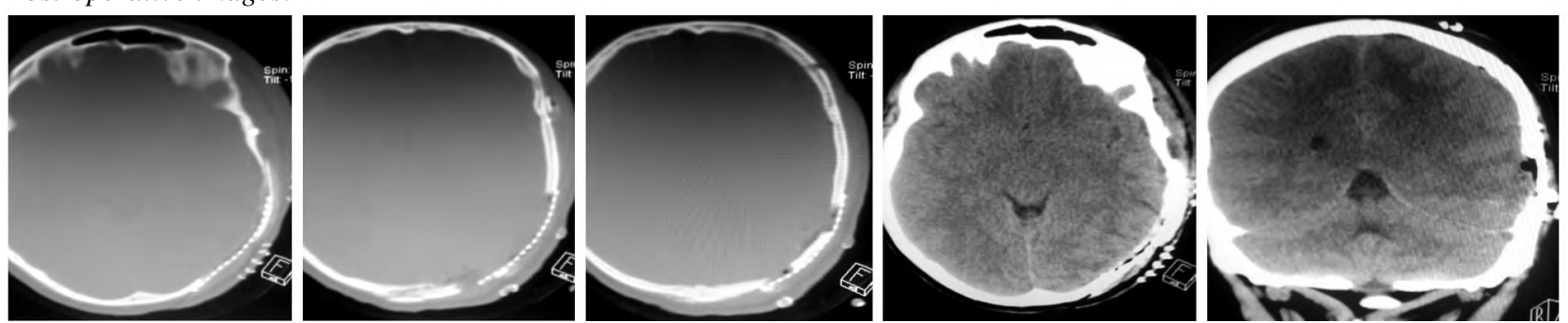

Patient improved clinically post-operative, CSF leak stopped and discharged after 10 days.

3- 36 years old male patient, presented to our center by frontal cosmetic defect following firearm injury in Yemen 4 months ago. He underwent bullet extraction and dural repair in another center in Yemen. Initial CT showed 2 frontal skull bone defects with underlying bilateral frontal brain contusions.

\section{Pre-operative images:}
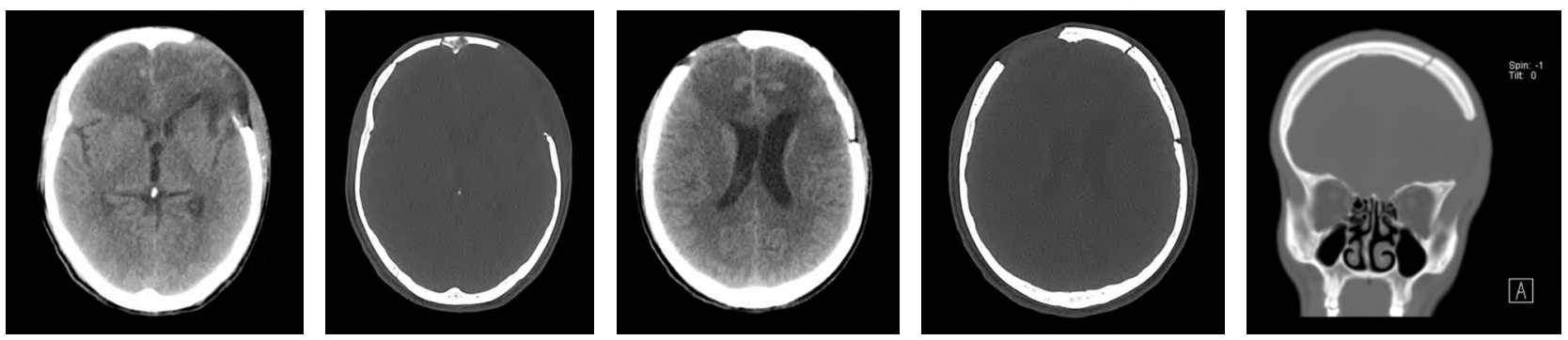

Post-operative images:
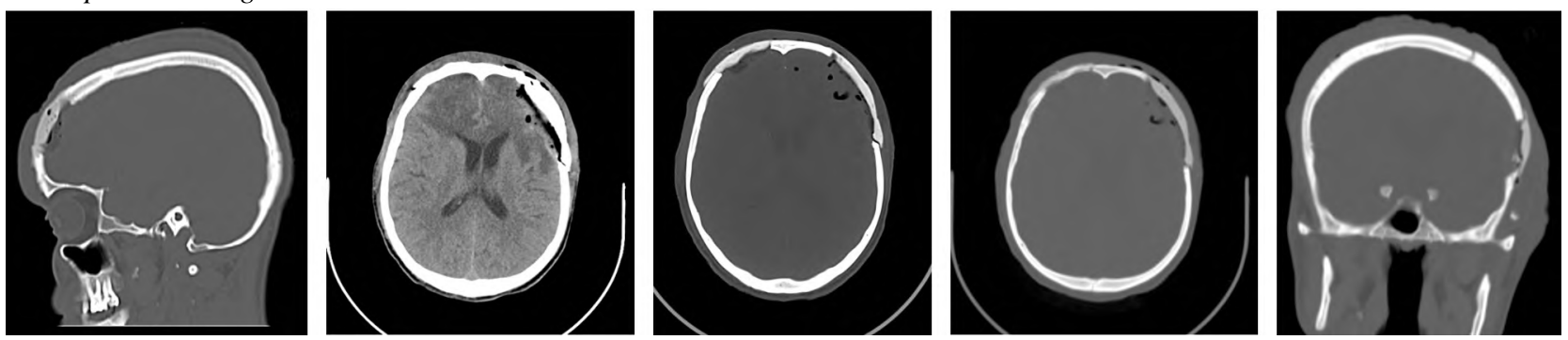

Patient underwent cranioplasty at 2 sites using bone cement, post-operatively there was subgaleal collection that delayed his discharge up to 2 weeks, aspiration of subgaleal collection with tight bandage under strong antibiotics umbrella was enough to control the condition.

\section{Conclusion:}

Using titanium mesh grafts in cranial bony defects following firearm injuries is the best option in terms of operation time, intra-operative bleeding loss, post-operative complications and cosmetic outcome.

Effective primary dural repair guards against formation of leptomeningiocele and CSF leaking fistulas that predispose to life-threatening CNS infections.

\section{References}

1- KIMBERLY S. MEYER and DONALD W. MARION: Textbook of critical care. 
2- RMONDA R.A., BELL R.S., VO A.H., LING G., DeGRABA T.J., CRANDALL B., et al.: Wartime traumatic cerebral vasospasm: Recent review of combat casualties.

3- MURANO T., MOHR A.M., LAVERY R.F., et al: Civilian craniocerebral gunshot wounds: An update in predicting outcomes. Am. Surg., 2005.

4- KYLE MUELLER, MICHAEL J. CIRIVELLO, RANDY S. BELL and ROCCO A. ARMONDA: Principles of Neurological Surgery.
5- ALDRICH E.F., EISENBERG H.M., SAYDJARI C., et al.: Predictors of mortality in severely head-injured patients with civilian gunshot wounds: A report from the NIH Traumatic Coma Data Bank. Surg. Neurol., 1992.

6- STUART E. MIRVIS, M.D., F.A.C.R., WAYNE S. KUBAL, M.D., et al.: Problem Solving in Emergency Radiology.

7- AARABI B., TAGHIPOUR M., ALIBAII E., et al.: Central nervous system infections after military missile head wounds.

\title{
ترقيع عظام الجمجمة ما بعل إصابات الطلق النارى للمصابين بحرب اليمنء دراسة مقارنة لـ بr مريض الهات النائ
}

\author{
ترقيع عظام الجمجمة هى عملية هعرفة بجراحات المخ والآعصاب، هدفها حماية آنسجة المخ وتحسين الشكل الجمالى اللمريض. \\ الهدف من الدراسة: مقارنة نتائج ترقيع عظام الجمجمة لمصابين الطلق النارى القادمين من اليمن بإستخدام شريحة تيتانيوم والآسمنت \\ تم إختيار المرضى بإستخدلام المعايير الآتية: \\ 1- حجم الجزء المفقود: تم إختيار المرضى ذات الجزء المفقود من عظام الجمجمة آكثر من זسم.

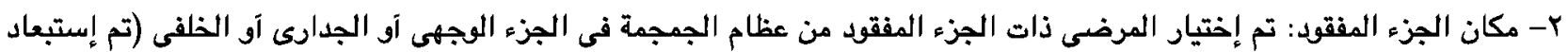

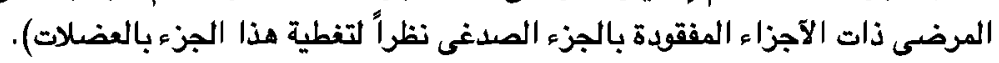

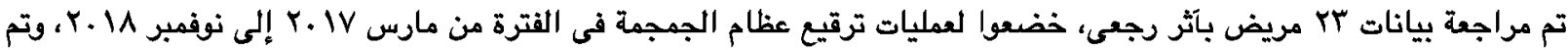

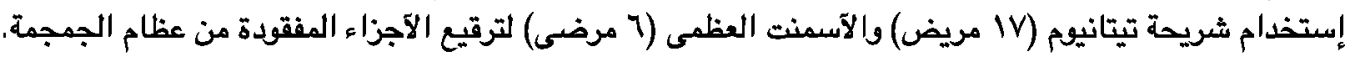 \\ النتائج: آكثر من ه9\% (rr مريض) خضعوا لعمليات إصلاح للجرح، إزالة الثظايا (فى بعض الحالات) في اليمن قبل المجئ إلى \\ المستشفى فى مصر.

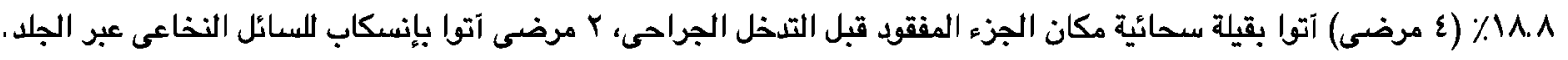 \\ آثناء الجراحة وجد آن Y.19٪ (19 مريض) لم يتم عمل ترقيع للآم الجافية بآى صورة فى الجراحة الآولى باليمن. \\ بغض النظر عن نوع المادة المستخدمة بالترقيع، 7.1\% (19 مريض) كانوا راضين عن الشكل الجمالى ما بعد التدخل الجراحى. \\ مجموعة شريحة التيتانيوم آظهروا معدلات مضاعفات آقل بالمقارنة مع مجموعة الآسمنت العظمى، بخصوص التجمعات المائية تحت الجلد \\ (T) \\ الإستستاجات: ترقيع عظام الجمجمة بإستخدام شريحة التيتانيوم آفضل من الآسمنت العظمى بخصوص معدلات المضاعفات ما بعد التدخل

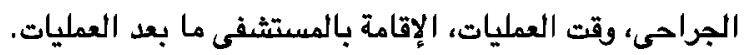

